\title{
OBITUARIES
}

\section{PROFESSOR J. A. BOYLE}

John Andrew Boyle was born at Worcester Park in Surrey in 1916. He received much of his early education from his father, a versatile bibliophile and bookseller, who had been the first editor of The Everyman Encyclopaedia, had revised Roget's Thesaurus, and had translated Spinoza's Ethics in to English, and excerpts from The Pickwick Papers into Portuguese for a Brazilian paper. The family moved to Birmingham where Boyle's father became Bolivian consul and he himself graduated with 1st Class Honours in German at the university. He then studied Oriental languages at Göttingen, where he was an appreciative pupil of H. H. Schaeder, and at Berlin. Returning to England in 1939 he became a postgraduate student at the School of Oriental and African Studies in London. In 1941 he became a sapper, though not for long. In the following year he was assigned to a special department of the Foreign Office where he remained until 1950. In 1945 he married a colleague, Margaret Elizabeth Dunbar, who gave him three daughters, a life of great domestic happiness, and constant support in his work, with difficulty maintaining some degree of order among his papers, and binding his numerous offprints. He was at last able to take his doctorate in 1947 under the supervision of Minorsky, whose admiring and admired pupil and friend he became, and who was the most important influence on his academic work. His thesis was concerned with a portion of Juvainīs history. In 1950 he was appointed to a newly created post as Senior Lecturer in Persian at Manchester University. Except for a year as Visiting Professor of Persian at the University of California (Berkeley) in 1959-60 he was to spend the rest of his career in Manchester, becoming a Reader in 1959 and Professor of Persian Studies in 1966. He died after a short illness on 19 November 1978.

Boyle compiled a small dictionary of Persian and a grammar of the modern language in the Porta linguarum orientalium series, but his principal publications were his annotated translations of Juvaini (The History of the World Conqueror, 1958), which was an extension of his doctoral thesis, of a part of Rashīd al-dīn (The Successors of Genghis Khan, 1971), and of the Ilähi-nāmeh of 'Ațtāar (1977). He edited volume V of the Cambridge History of Iran, "The Saljuq and Mongol periods", to which he contributed a notable chapter, "Dynastic and political history of the IIl-Khāns". In collaboration with his friend Professor Karl Jahn he edited a special volume of the Central Asiatic Journal commemorating Rashīd al-dīn (1970). In addition he contributed numerous articles to academic journals, twenty-four of which were collected in The Mongol World Empire (1977).

His linguistic.equipment was formidable and was not restricted to the usual classical, Romance, Teutonic, and Near Eastern languages. He had a working 
knowledge of Russian; unlike many Persian scholars in Britain he had some acquaintance with pre-Islamic Iranian; he knew Welsh and he had studied Old Irish in Berlin; when a civil servant he acquired a knowledge of Armenian. In his later years he became more and more interested in folklore, where all these accomplishments were put to good use. He had been on the Committee of the Folklore Society since 1973 and published some valuable articles in its journal Folklore.

Though Boyle wanted above all to be left in peace to do his own work, he was a friendly and sociable man who took a prominent part in several learned societies and co-operative projects. He joined this Society in 1944 and delivered the Clauson Memorial Lecture in May 1978. He had been on the Council of the British Institute of Persian Studies since 1964, on the editorial board of the Cambridge History of Iran since 1966, a Gibb Memorial Trustee since 1970, and on the Council of the British Society for Middle Eastern Studies since 1973. He was a co-founder of the Anglo-Mongolian Society and had been its Chairman since 1970. He was active in the Permanent International Altaistic Conference and was twice its host in Manchester. His achievements were not unrecognized in other countries. In 1958 he received the Iranian order and decoration of Sepass, being the only European ever to have been honoured in this way. He had been a member of the Advisory Board of Iran Shenasi since 1969. In 1973 he was elected an Honorary Fellow of the Körösi Csoma Sándor Társaság of Budapest. He joined the Editorial Board of the international Central Asiatic Journal in 1977 and was to have succeeded Jahn as editor-in-chief.

Boyle's interest was in the meaning and derivation of words, the identification of persons and places mentioned in texts, and the dating of events. The more complicated such problems were, the more he enjoyed them. He was never happier than when trying to extricate the correct form of a Turkish or Mongol name from a transcription in unvowelled and preferably undotted Arabic characters. It was this predilection which made him such a superb translator and annotator of Juvain̄i and Rashīd al-dīn. His object was to derive from the sources as accurate a narrative of events as possible, but he was by no means insensitive to imaginative literature. He was genuinely fond of Persian poetry,

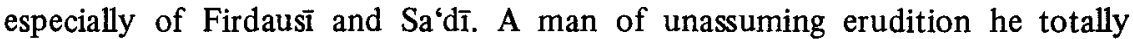
eschewed showmanship himself, but he was neither offended nor influenced by the showmanship of others. Unfailingly patient and courteous with the eccentric, the stupid, and the ignorant, he never emphasized trivial errors to be found in the writings of the great scholars of the past. He talked about men like Nöldeke, Browne, and Nicholson, and indeed many others far less eminent, in terms of almost personal gratitude. He was always scrupulous in acknowledging any help he had received from even the most obscure and improbable quarter, whether from a colleague, an acquaintance, a correspondent, or the long 
forgotten works of a long-dead author. Throughout his life, like the Clerk of Oxenford, "of studie took he most cure and most hede", and at all times, with all people, in all circumstances, "gladly wolde he lerne and gladly teche".

C. F. BECKINGHAM.

\section{WILLIAM GEORGE ARCHER, O.B.E., M.A., D.Litt.}

William Archer, who died on the 6th March aged 72, will long be remembered for his major contributions to the study of both Indian tribal culture and Indian painting. After reading history at Emmanuel College, Cambridge, he aspired to a mandarin existence in Whitehall, hoping for leisure to indulge his interests in poetry and modem art. His success in the combined Home and Indian Civil Service Examinations was, however, marred by loss of marks for bad handwriting. As a result, in 1931, he found himself posted to Bihar as a member of the I.C.S.

Unexpectedly, rural India proved as vital a stimulus to his interests as life in London would have done, for already in his first year out, when on tour for tiger, he found himself far more excited by primitive images of the cattle god, Bir Kuar, than by any tiger. If these sculptures set in the remote Indian countryside reminded him of Negro, Celtic, or modern European works, the symbolic imagery of Uraon folksongs from the neighbouring Ranchi district seemed to offer a remarkable parallel to that of modern western verse. This he demonstrated in his first book, The blue grove (1940), in which sensitive translations of Uraon songs that he had collected were accompanied by a scholarly introduction on the tribal background. Meanwhile, after his marriage in 1934, he and his wife, Mildred, revisited West Bihar, where he again studied the Ahir cult and images of Bir Kuar. This resulted in his second book (1947), whose title, The vertical man, was a quotation from a poem of W. H. Auden.

After his initial period as a Sub-Divisional Officer he served as District Magistrate in Purnea and then, having spent the early years of the war as Superintendent of the Census in Bihar, he became District Magistrate of Patna in a particularly difficult period (1941/2). It was during these postings that he had opportunities for touring extensively, discovering the Picasso-like qualities of Mali and Maithil paintings as well as studying and collecting various other types of primitive art. Later, as Deputy Commissioner of the Santal Parganas (1942-5), he became an authority on Santal tribal customs and was sub. subsequently appointed as Special Officer entrusted with the task of investigaing Santal Law. During this period he also acted as editor of Man in India (1942-9). The field-work from these years with his beloved Santals bore fruit 